Asia Proceedings of Social Sciences

(APSS)

www.readersinsight.net/APSS

\title{
Legal Analysis \\ Contradictory Regulations on the Granting of Sanctions on Environmental Social Responsibility in Indonesia
}

Rise Karmilia*

Faculty of Law, University of Pasir Pengarayan Indonesia

*Corrosponding author's Email: karmiliarise@gmail.com

Peer-review under responsibility of $4^{\text {th }}$ Asia International Conference 2018 editorial board (http://www.utm.my/asia/our-team/) (C) 2018 Published by Readers Insight Publisher, lat 306 Savoy Residencia, Block 3 F11/1,44000 Islamabad. Pakistan, info@readersinsight.net This is an open access article under the CC BY-NC-ND license (http://creativecommons.org/licenses/by-nc-nd/4.0/). 


\section{Research High Iights}

Indonesia mentions the term Corporate Social Responsibility with Environmental Social Responsibility. Then this was abstracted into the positive law of Indonesia so that contributing voluntary activities for human transformation became an obligation. These obligations are set forth in the Corporate Social Responsibility, as well as this becomes a differentiator from other countries. In the development of regulations regarding Environmental, Social Responsibility experiencing a variety of problems including the absence of synchronization of law, the view that Environmental Social Responsibility is an obligation, then has an effect on the provision of sanctions given to companies that do not carry out Social Responsibility. This research proposes that a regulation be renewed on social environmental responsibility so that harmonization in the rule of law occurs and can maximize law enforcement and sanctions in Social Responsibility.

\section{Research Objectives}

The purpose of this research is to explain the rule of law which contains a discussion of social environmental responsibility. As well as finding out the non-synchronization of legal rules with one another. Then it will be examined the consequences of such synchrony, especially regarding the determination of legal status in the implementation of Environmental Social Responsibility along with the provision of sanctions if the company does not implement Environmental Social Responsibility.

\section{Methodology}

This study uses a normative juridical method and the type of data used is secondary data. Obtained through literature study, namely by conducting research on various library sources such as books, official documents, results of research in the form of reports, legislation relating to regulations regarding environmental social responsibility. Data obtained through library studies is collected and sorted, then organized in one pattern, basic description category and unit. Data analysis of this writing is in a qualitative way. 


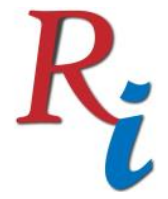

\author{
Asia Proceedings of Social Sciences \\ (APSS) \\ www.readersinsight.net/APSS
}



\title{
Results
}

The unclear rules in the implementation of the Company's Environmental Social Responsibility cause differences in interpretation (Nurul Listiyani: 2013). This can be seen not all regulations view Environmental Social Responsibility as an obligation (Raden Roro Kusumaningayu Mukti Wijayanti: 2014) as well as differences in sanction arrangements if the Corporate Social Responsibility program is not carried out by the company. The difference in interpretation was born when the government implemented Corporate Social Responsibility as Environmental Social Responsibility in accordance with regulations in Indonesia. Laws on Limited Liability Companies and Government Regulations on Environmental Social Responsibility no longer use Corporate Social Responsibility but use Environmental Social Responsibility that is tailored to the business culture in Indonesia. This has resulted in a debate between business actors and the government because by changing the terms and concepts into Environmental Social Responsibility, the business actor can no longer voluntarily implement Social Responsibility, but rather turns into an obligation. This is reinforced by the Decision of the Constitutional Court of the Republic of Indonesia on the lawsuit against the testing of Material and Formil on the legal basis of Environmental Social Responsibility contained in the Limited Liability Company Law which contains an explanation of the obligation to implement Social Responsibility. The result of the Constitutional Court's decision is that it cannot accept the applicant's request for material and formal testing.

\section{Findings}

Law enforcement of Environmental Social Responsibility was not carried out optimally because of the regulatory disagreement regarding sanctions. However, what can be done to maximize law enforcement is to reform the legal system (Lawrence M. Friedman: 2011), specifically related to legal substance (Otje Salaman \& Anton F. Susanto: 2004). Because the substance of the law is the basis for law enforcement agencies in carrying out law enforcement actions on Social Responsibility. In order to function, the legal substance needs to pay attention (Alvi Syahrin: 2009).

1. Interpretation of the determination of the rights and obligations of the subject through the process of applying the rules.

2. Sanctions confirm what sanctions are, how they are implemented and who applies them.

3. Jurisdiction determines the line of authority and class that the norms want to regulate. 


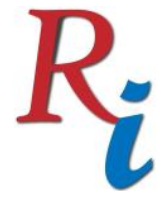

Asia Proceedings of Social Sciences

(APSS)

www.readersinsight.net/APSS

\section{References}

Lawrence M. Friedman: 2011, Sistem Hukum : Perspektif Ilmu Sosial, diterjemahkan oleh M. Khozim dari buku The Legal System : A Social Science Perspective, Bandung, Penerbit Nusa Media.

Nurul Listiyani: 2013, Memaknai Sanksi Hukum Dalam Pelaksanaan Corporate Social Responsibility (TJSLP), Februari, Kopertis 11. Volume 5 Nomor 1.

Otje Salaman \& Anton F. Susanto: 2004, Teori hukum, mengingat, mengumpulkan dan membuka kembali, refika aditama Bandung.

Raden Roro Kusumaningayu Mukti Wijayanti: 2014, Pertanggungjawaban pidana korporasi yang tidak melaksanakan corporate social responsibility. Universitas Brawijaya.

Syahrin Alvi: 2009, Beberapa Isu Lingkungan Kepidanaan, Medan, Soft Media. 